\title{
Emily Dickinson's Placenames
}

\author{
Malina Nielson \\ and \\ Cynthia L. Hallen \\ Brigham Young University
}

Emily Dickinson used at least 162 placenames, or toponyms, in her poetic vocabulary. Approximately 195 of Dickinson's 1,789 poems employ at least one placename, more than one tenth of the poetic corpus. Of the 162 placenames in Dickinson's poems, 70 refer to places in Europe, 17 to the Middle East, 12 each refer to Africa and North America, 11 each to Central America and Eurasia, 10 each to Asia and South America, and 1 reference each to Austronesia and the North Pole. In addition, Dickinson makes 7 references to sacred space and outer space. Dickinson refers to 29 different kinds of topographic entities: choronyms such as continents, oikonyms such as cities, oronyms such as mountains, hydronyms such as rivers, astronyms such as planets, and miscellaneous features such as languages, gardens, battle sites, or churches. The best resources for studying Dickinson's toponyms are Noah Webster's American Dictionary of the English Language (1828-1844) and the Oxford English Dictionary. To consolidate and augment the information in these and other resources, we have defined all of the toponyms in Dickinson's poetic lexicon for the forthcoming Emily Dickinson Lexicon.

A thorough understanding of Emily Dickinson's poems requires careful attention to her diction, including proper names such as toponyms. In her lyrical poems, Dickinson includes the names of 162 different local, regional, national, and international places, even though she lived most of her life (1830-1886) in one New England town: Amherst, Massachusetts.

Approximately 195 of Dickinson's 1,789 poems employ at least one placename, more than one tenth of the poetic corpus. The placenames appear regularly across the span of her writing career from 1852 to 1885 , from "Bunker Hill" in one of the first poems (Fr2/J3) to "Ethiopian" in one of the last

Names 54:1 (March 2006):3-22

ISSN:0027-7738

Copyright 2006 by The American Name Society 
poems (Fr1678v/J1644). About one fourth of the 195 toponym poems feature 2 to 4 different placenames, but a majority of those poems contain just one toponym.

Dickinson's geographic references range in places "From Amherst to Cashmere!" (Fr176/J179). Of the 162 placenames in Dickinson's poems, 70 refer to places in Europe, 17 to the Middle East, 12 each refer to Africa and North America, 11 each to Central America and Eurasia, 10 each to Asia and South America, and 1 reference each to Austronesia and the North Pole. In addition, Dickinson makes 7 references to sacred space and the solar system. Table 1 shows which geographic areas have the most placenames as unique Dickinson toponyms in 10 major areas of the world:

Table 1: Geographic Areas for Dickinson's Placenames by Frequency

\begin{tabular}{ll}
\hline Area & Distinct Placenames \\
\hline Europe & 70 \\
\hline Middle East & 17 \\
\hline North America & 12 \\
\hline Africa & 12 \\
\hline Central America & 11 \\
\hline Eurasia & 11 \\
\hline Asia & 10 \\
\hline South America & 10 \\
\hline Sacred Space and the Solar System & 7 \\
\hline Austronesia and the North Pole & 2 \\
\hline Total & 162 \\
\hline
\end{tabular}

The poems include 33 unique toponyms for the Americas as a whole, with 120 total references to Africa, Asia, Eurasia, Europe, and the Middle East. The 3 to 1 preponderance of Old World references to New World toponyms may be due to the classical track in Dickinson's education, as well as the 
relatively short time since the United States of America had emerged as a nation in 1776.

Dickinson refers to many different kinds of topographic entities: choronyms such as continents, countries, and regions; oikonyms such as towns and cities; oronyms such as hills, mountains, and volcanoes; hydronyms such as seas and rivers; astronyms such as planets and constellations; and miscellaneous features such as languages, gardens, battle sites, churches, cemeteries, and quarries. Cities are the most frequent toponymic entity that Dickinson mentions, with 28 tokens. Countries are next in number, with 16 different nations mentioned in the poems.

\section{Europe}

Dickinson's poems contain more references to Europe than to any other continent, both in unique placenames and overall occurrences. The high number of European placenames is not surprising since many Amherst families had historical ties to lands in Europe. Furthermore, Dickinson may have shared in the perception that "the most accomplished artists in all cultural forms . . . came from Europe" (Eberwein 1996, 177-178). Many well-known nineteenth-century New England writers, such as Noah Webster, Ralph Waldo Emerson, Harriet Beecher Stowe, and Louisa May Alcott, completed tours of Europe to enhance their education, bolster their writing, or expand their literary connections. Although Dickinson never made the grand tour, she traveled Europe poetically, rhetorically, and philologically from her home base in Amherst.

In Dickinson's poems, European choronyms (areal features) include countries, cultures, languages, nationalities, and regions: Anglo-Florentine, Arragon, Austrian, Biscayan, Bohea, Bourbon, British, Burgundy, Corinthians, Danes, English, Etruscan, Finland, Greek, Italic, Italy, Lapland, Latin, Norseman, Saxon, Spartan, Swiss, Thessaly, and Yorkshire. Dickinson's European oikonyms (entailing human settlement) include 


\section{8 - NAMES 54:1 (March 2006)}

several cities and towns: Athens, Birmingham, Brussels, Durham, Exeter, Frankfort, Geneva, Genoa, Ghent, Haworth, Hybla, Kidderminster, Liverpool, Manchester, Naples, Paris, Pompeii, Pyrrhenees, Vatican, Venice, and Vevay.

European hydronyms in Dickinson's poems include seas, rivers, and an island: Baltic, Dneiper, Don, Rhine, and Sicily. Dickinson's European oronyms include mountain ranges, peaks, passes, hills, and volcanoes: Alps, Appenine, Etna, Thermopylae, and Vesuvius. Miscellaneous toponym entities include the names of famous church buildings in Europe, as well as dyes, porcelain, quarries, and marble: Carrara, Lincoln, Parian, Sevres, St. James, and Westminster.

In an 1862 poem, Dickinson combines a the toponym "Lapland" with three other north European placenames: "Norwegian," "Don," and "Dneiper":

I think the Hemlock likes to stand

Opon a Marge of Snow -

It suits his own Austerity -

And satisfies an awe

That men, must slake in Wilderness -

And in the Desert - cloy -

An instinct for the Hoar, the Bald -

Lapland's - nescessity - [sic]

The Hemlock's nature thrives - on cold -

The Gnash of Northern winds

Is sweetest nutriment - to him -

His best Norwegian Wines -

To satin Races - he is nought -

But Children on the Don,

Beneath his Tabernacles, play,

And Dnieper Wrestlers, run. (Fr400/J525) 
On the surface of the poem, the "Northern Winds" of "Lapland" phonetically and semantically echo the "Norwegian Wines" that nourish hemlock trees and quench the thirst of people in the wilderness. On a deeper level, the essence of "Lapland" figuratively and metaphorically typifies the poetry of the New England recluse Emily Dickinson: lyric verse that is compact, focused, spare, thrifty, economical, intellectual, chaste, and spiritual. Although Dickinson's poetry is "refined, minimalist, and severe" (Mitchell 2000, 79), the pristine "Snow" of her life-giving language cloys the hunger and slakes the thirst of conscientious readers.

\section{Middle East}

Dickinson refers to the Bible more than any other source in her poems, and most of Dickinson's Middle Eastern toponyms are Biblical allusions. The Middle East placenames in Dickinson's poems include 5 choronyms (Canaan, Judea, Nazarene, Ophir, Persian); 4 oikonymns (Bethlehem, Jerusalem, Nazareth, Zion); 3 oronyms (Calvary, Nebo, Peniel); and 2 hydronyms (Jordan, the Red Sea). Miscellaneous entities include a garden (Gethsemane) and the royal purple dye from the ancient city of Tyre (Tyrian).

The Middle East placename "Calvary" is the second most frequent Dickinson toponym, appearing in 12 poems. "Calvary" refers to the literal location of Christ's crucifixion just outside of Jerusalem in the Holy Land, but it is also a metonym for the internal topos of ordinary people when they experience excruciating pain.

Dickinson groups "Calvary," "Gethsemane," and "Judea" together in an 1863 poem, charting a topography of the soul as well as a geography of the Holy Land:

One Crucifixion is recorded - only

How many be

Is not affirmed of Mathematics -

Or History 
One Calvary - exhibited to Stranger As many be

As Persons - or Peninsulas -

Gethsemane -

Is but a Province - in the Being's Centre Judea -

For Journey - or Crusade's Achieving -

Too near -

Our Lord - indeed - made Compound Witness -

And yet -

There's newer - nearer Crucifixion

Than That - (Fr670/J553)

In two other poems, Dickinson pairs the toponyms "Calvary" and "Gethsemane," reinforcing the theme of Christ's infinite sacrifice for humanity (Fr283/J313; Fr1485/J1432).

\section{North America}

Dickinson's references to the northern half of the western hemisphere include one occurrence of the continent North America. The remaining 11 North American placenames are national, local, and patriotic toponyms in the United States, including the region of New England and the state of Maryland. Oikonyms include Dickinson's hometown of Amherst, as well as the towns of Bethleem (in New Hampshire) and Lexington (in Massachusetts). Other entities include the battle site Bunker Hill and the cemetery Auburn.

"Auburn" is a North American placename with metaphoric extensions, sense play, and a literary allusion in an 1858 poem:

When Roses cease to bloom, Sir, 
And Violets are done -

When Bumblebees in solemn flight

Have passed beyond the Sun -

The hand that paused to gather

Opon this Summer's day

Will idle lie - in Auburn -

Then take my flowers - pray! (Fr8/J32)

A textual note in the Johnson variorum edition states that "Auburn" is an allusion to Mount Auburn Cemetery in Cambridge, Massachusetts, which Dickinson visited in August 1846. Impressed with its solemnity, she called Auburn's burial ground the "City of the Dead" in a letter to a friend (L29). She may also be alluding to a European placename: William Goldsmith's nostalgic portrayal of "Sweet Auburn, loveliest village of the plain" in his 1770 English poem "The Deserted Village."

On the surface of the poem, "Auburn" is a phonological pun on "Autumn," pointing to the season of falling and decaying leaves. Autumn in New England evokes figurative senses of death and the grave. Both the OED and Webster's 1828 ADEL entries define "Auburn" as a color, but neither dictionary mentions figurative senses, nor do they include "Auburn" as a placename.

\section{Africa}

Dickinson's choronyms in Africa include adjective forms of the continent (African) and two countries (Ethiopean and Lybian). The poet refers to two oikonyms: the town of Timbuctoo and the city of Tunis. She mentions the language of Egyptian, the desert of Sahara, the volcano Teneriffe, the province of Tripoli, the island of Zenzibar, and the textile Fustian from a suburb of Cairo.

The majority of Dickinson's "geographical names are those that appear in the maps and texts of Peter Parley's geography" (Patterson 1979, 141). In school books by "Peter 
Parley" (pen name of Samuel Griswold Goodrich ), Dickinson would have read that leaders of the North African port Tripoli declared war on the United States in order to inhibit trade via the Mediterranean in the early 1800's (Goodrich 1873, 161-162). Dickinson mentions of the "right of way to Tripoli" in the following 1884 New England nature poem:
The pedigree of Honey
Does not concern the Bee,
Nor lineage of Ecstasy
Delay the Butterfly
On spangled journeys to the peak
Of some perceiveless thing - The right of way to Tripoli
A more essential thing.

(Fr1650A/J1627A)

In 1804, the U.S. Navy won the battle of Tripoli, marking the first time that the American flag was raised in a foreign land for a military victory. The raising of the star-spangled banner at Tripoli to declare right of passage parallels Dickinson's "spangled journeys to the peak / Of some perceiveless thing." The "perceiveless thing" is liberty, which is a "more essential thing" for freedom-loving residents of New England, such as the "Butterfly" and the "Bee."

Central America and South America

Dickinson's references to Central American placenames include the general term America, the Indies of Columbus, and the adjective form West-Indian. Dickinson specifies island locations in Central America: the Bahamas, St. Domingo, and Jamaica. The country of Balize and the volcano Popocatapetl also appear in Dickinson's poems. In addition, she mentions the country of Mexico and two of its cities: Manzanilla and Vera Cruz.

Dickinson refers to the continent of South America and to three countries therein: Bolivian, Brazil, and Peru. The poems include 
two South American cities: Buenos Ayre in Argentina and Potosi in Bolivia. Dickinson mentions two mountain ranges (Andes and Cordillera) and one volcano (Chimborazo). She uses placenames in Central and South America to evoke exotic forces, spiritual adventures, and rich natural resources.

\section{Asia and Eurasia}

Toponyms for Asia and Eurasia in Dickinson's poems likewise represent concepts of wealth and the beauty of nature. Dickinson focuses on places in western Asia and has no direct references to places such as China or Japan in the Far East. In addition to the noun Asia and the adjective Asiatic for the continent, she refers to the countries of Burmah and India. The poet cites the region of Cashmere, the city Golconda, and the Himmaleh mountain range. She mentions Indiaman and Malay as nationalities.

The Asian toponym "Burmah" has not received much attention in Dickinson studies, and Webster's 1828 dictionary does not have an entry for it. In this 1879 Dickinson poem, the placename "Burmah" is rich in metaphor:

One of the ones that Midas touched

Who failed to touch us all

Was that confiding Prodigal

The reeling Oriole -

So drunk he disavows it

With badinage divine -

So dazzling we mistake him

For an alighting Mine...

The splendor of a Burmah

The Meteor of Birds,

Departing like a Pageant

Of Ballads and of Bards - ...

(Fr1488/J1466) 
In the poem, the placename "Burmah" is a synonym for the oriole, a gold-colored bird. After receiving a bluebird poem from Dickinson (Fr1484/J1465), novelist Helen Hunt Jackson encouraged her to write a poem about an oriole (textual note in the Johnson edition). Although Dickinson's "reeling Oriole" is common in North America, the species also lives in Burmah (now Myanmar), famous for its golden mineral riches.

Dickinson refers to several places on the Eurasian frontier between present-day Europe and Asia. The majority of the Eurasian placenames are hydronyms: Azof, Bosporus, Caspian, and Mediterranean. The Eurasian poems also include the mountain peak Ararat, the Circassian region, the town Gibralter, and the nationality Turk.

Syntactic parallelism enhances the meaning of the toponym "Azof" in this 1869 nature poem:

The duties of the Wind are few -

To cast the ships at Sea,

Establish March, the Floods escort,

And usher Liberty.

The pleasures of the Wind are broad,

To dwell Extent among,

Remain, or wander,

Speculate, or Forests entertain -

The kinsmen of the Wind, are Peaks

Azof - the Equinox,

Also with Bird and Asteroid

A bowing intercourse -

The limitations of the Wind

Do he exist, or die,

Too wise he seems for Wakelessness, 
However, know not I - (Fr1160/J1137)

In the third stanza, the word "Azof" is not a postponed adjective modifying the noun "Peaks" at the end of the previous line. Rather, it is a proper noun referring to the Sea of Azof on the border between Europe and Asia, the second item in a catalog of natural phenomena that are "kinsman of the Wind." The Peaks, Azof, the Equinox, Bird, and Asteroid constitute a list that is syntactically parallel to the "duties of the Wind," the "pleasures of the Wind," and the "limitations of the Wind" in the other stanzas of Dickinson's poem.

\section{Austronesia and The North Pole}

Dickinson makes one reference to a placename in the south Pacific islands of Austronesia: Van Dieman's Land. "Van Dieman's Land" is Dickinson's variant spelling of "Van Diemen's Land, the island now known as "Tasmania." The island, just south of Australia, was named after Anthony Van Diemen, the governor of the Dutch West Indies." Dickinson could have seen it on Peter Parley's map of the Eastern Hemisphere (Goodrich 1873, 17). In the 1862 poem below, Dickinson uses Van Dieman's Land as a metaphor for the farthest extremities of existence:

If you were coming in the Fall,

I'd brush the Summer by

With half a smile, and half a spurn,

As Housewives do, a Fly.

If I could see you in a year,

I'd wind the months in balls -

And put them each in separate Drawers,

For fear the numbers fuse -

If only Centuries, delayed,

I'd count them on my Hand, 
Subtracting, till my fingers dropped Into Van Dieman's Land .... (Fr356/J511)

In stanza one of the poem, a lover says she would gladly forego the delights of Summer if the beloved were returning in the Fall season. In stanza two, the lover would wind up the 365 days of the year into twelve separate balls of yarn to make time go faster. In stanza three, she would count hundreds of years on just five fingers until the numbers dropped to zero or into oblivion. Whether the lover has to wait one season, twelve months, five centuries, or an "Eternity," she wants to believe that she will be reunited with her beloved, even though waiting without a set date for reunion is painful. The longing for reunion with the beloved is reminiscent of Lady Jane Franklin's devotion to her explorer husband, Sir John Franklin, who died in the Arctic ten years after serving as governor of Van Diemen's Land (see Fr957/J851).

In four poems, Dickinson refers to a toponym in the North Pole: the Arctic. She uses the adjective Arctic in an 1865 poem that also alludes to Lady Franklin: "When the lone British Lady / Forsakes the Arctic Race" (Fr957/J851). An 1860 Dickinson poem, the wintry "Arctic flower" on the "polar hem" is an antonym of places like "Eden" in the southern tropics (Fr177/ J 180).

\section{Sacred Space and Outer Space}

Dickinson's toponyms include names for the spirit world, planets, and other heavenly bodies. She refers to three gardens (Eden, Elysium, Hesperian), a group of islands (Hesperides), and a river (Lethe) in mythical or sacred space: The placename "Eden" is the most frequent Dickinson toponym, appearing in 17 poems; furthermore, "Eden is one of the most meaningful of symbols" that the poet explores (Capps 1966, 31). Our entry for the Emily Dickinson Lexicon shows that the poet uses "Eden" to refer to sacred space in heaven and on earth: 
A. Biblical garden; primordial state; cradle of civilization; birthplace of mankind; abode of our first parents; sinless state of the world before Adam and Eve's fall and expulsion; paradise.

Fr378/J1503 Brooks in Eden - / Bubbled a better melody ... Eve's great surrender

B. After-life; spirit world; Elysium; life after death and before the resurrection; resting place of the dead before the final judgment.

Fr437/J413 I dont like Paradise ... Eden'll be so lonesome ... God . . . Himself . . . beholds us . . . But there's the "Judgment Day"!

C. Heaven; eternity; immortality; mansion on high; paradisiacal glory; kingdom of God; dwelling place in the presence of the Lord.

Fr241/J215 What is - "Paradise" . . Do they wear "new shoes" - in "Eden" ... Wont they ... tell God

D. Harbor; cove; inlet; [fig.] haven; security; calm; shelter; safe place; back water bay; place free of danger and evil; [historical] East Eden, Maine; port where Samuel Bowles learned to row.

Fr269/J249 Rowing in Eden ... Might I but moor tonight - / In thee!

E. The Tropics; heaven on earth; tropical paradise; promised land; place full of flowers, sunshine, and birds; [synonym] Brazil.

wandered in

Fr177/J180 some little Arctic flower . . . To Eden,

F. Spring; summer; season of new life; beauties of nature; time of growth and verdure; [fig.] pleasure; delight; ecstasy; innocent enjoyment; state of bliss.

Fr205/J211 Come slowly - Eden!

G. Now; today; mortality; this life; present time; [historical] Amherst, Massachusetts; home of the Dickinson family.

Fr1734/J1657 Eden is that old fashioned House / We dwell in every day

In addition to toponyms for sacred space, Dickinson refers to two astronyms: the constellation Capricorn and the planet Saturn. 


\section{Conclusions}

Emily Dickinson used at least 162 placenames, or toponyms, in her poetic vocabulary to refer to literal and figurative domains. Although some of Dickinson's toponyms are comprehensible to contemporary readers, the meaning of other names can seem obscure without careful exploration in dictionaries, other scholarly works, and the poems themselves.

The best resources for studying the poet's toponyms are dictionaries: Noah Webster's American Dictionary of the English Language (ADEL), which Dickinson used at Amherst Academy (Lowenberg 105), and the Oxford English Dictionary (OED), which includes word meanings attested in the nineteenth century. Toponym dictionaries are also useful (Blackie, 1968; Engeln, 1970; Room, 1992; Room, 1997; Urdang, 1987). To consolidate and augment the information in such resources, we have compiled all of the toponyms in Dickinson's poetic vocabulary for inclusion in the forthcoming Emily Dickinson Lexicon (see Table 2).

Several scholars have noticed the importance of exploring the contexts and connotations of Dickinson's toponyms (see Browner, 2004; Eberwein, 1996; Farr, 2004; Hamada, 1998; Palmer, 1976; and Silva Gruesz, 2004). In a discussion of "Emily Dickinson's Poetic Vocabulary," William Howard identifies several placenames, but he does not elaborate on their interpretation in Dickinson's poems. Jack Capps does elaborate on the meaning of 45 placenames in Dickinson's poetry for his groundbreaking book on Emily Dickinson's Reading. Additionally, the Dickinson Electronic Archives (DEA) website includes a handy list of "places, organizations, and ships" relevant to Dickinson's works and biography; however, the majority of placenames in the DEA database are not yet completely defined. 
In summary, those who explore the intricate web of Emily Dickinson's placenames will travel lexically to the four corners of the earth. A careful examination of toponyms helps readers and translators answer questions that Dickinson herself poses:

Nor Mountain hinder Me
Nor Sea -
Who's Baltic
Who's Cordillera? (Fr1

Because Dickinson "searched philology" (Fr1243/J1126) and read Webster's "Lexicon" religiously (L261), the rewards for researching toponyms can be great. Although "finding Nebo" may not lead to revelation, and wrestling with "Peniel" may not grant a face-to-face divine interview, Dickinson's placenames open vistas of metaphor, meaning, emotion, history, understanding, and semantic layering.

\section{References}

Unless otherwise indicated, the following abbreviations are used for reference to the writings of Emily Dickinson and Thomas Wentworth Higginson:

Fr R.W. Franklin, ed. 1998. The Poems of Emily Dickinson. 3 vols. Cambridge: Harvard University Press. Citations by poem number.

J Thomas H. Johnson, ed. 1955. The Poems of Emily Dickinson. 3 vols. Cambridge: Harvard University Press. Citation by poem number.

L Thomas H. Johnson, ed. and Theodora Ward. 1958. The Letters of Emily Dickinson. 3 vols. Cambridge: Harvard University Press. Citation by letter number.

Beech, Martin. 2005. W.F. Denning: In Quest of Meteors. Regina, Canada: University of Regina. http://hyperion.cc.uregina.ca/ astro/DEN/Intro.pdf. Benvenuto, Richard. 1983. "Words Within Words: Dickinson's Use of the Dictionary." ESQ 29:46-55.

Bianchi, Martha Dickinson. 1936. The Poems of Emily Dickinson: Centenary Edition. Boston: Little, Brown. 
The Bible, King James Version. 1979. Salt Lake City: The Church of Jesus Christ of Latter-day Saints.

Blackie, C. A Dictionary of Place-Names: Giving their Derivations. $3^{\text {rd }}$ ed. Detroit: Gate Research Co, 1968.

Browner, Stephanie. 2004. "Love and Conquest: the Erotics of Colonial Discourse in Dickinson's poems and letters." The Classroom Electric: Dickinson, Whitman, and American

Culture. http:/ / jefferson.village.virginia.edu/fdw/volume1/br owner2/index.html.

Capps, Jack. 1966. Emily Dickinson's Reading: 1836-1886. Cambridge, Massachusetts: Harvard University Press.

Crystal, David. 2000. The Cambridge Encyclopedia of Language. Cambridge: Cambridge University Press.

Dickinson Electronic Archives website. 2004. http://www.emilydickinson.org/databases/.

Eberwein, Jane Donahue. 1996. "'Siren Alps': The Lure of Europe for American Writers." Emily Dickinson Journal, 5(2):176-182.

Ellis, Richard S. 1999. "'A little East of Jordan': Human-Divine Encounter in Dickinson and the Hebrew Bible." Emily Dickinson Journal, 8(1):36-58.

Engeln, O.D. von and Jane McKelway Urquhart. The Story Key to Geographic Names. Port Washington: Kennikat Press, 1970.

Farr, Judith with Louise Carter. 2004. The Gardens of Emily Dickinson. Cambridge: Harvard University Press.

Goldsmith, Oliver. 2005. "The Deserted Village, a Poem." Representative Poetry Online. http://eir.library.utoronto.ca/rpo/display/ poem875.h tml

Goodrich, Samuel Griswold. 1837. A System of School Geography: Chiefly Derived from Malte-Brun, and Arranged According to the Inductive Plan of Instruction. New York: F.J. Huntington.

1873. Peter Parley's Universal History, on the Basis of Geography. New York: Ivison, Blakeman, Taylor. 
Hamada, Sahoko. 1998. "Geographic Images." An Emily Dickinson Encyclopedia. Ed. Jane Donahue Eberwein. Westport: Greenwood Press, 123-124.

Howard, William. 1957. “Emily Dickinson's Poetic Vocabulary." PMLA 72:225-248.

Lowenberg, Carlton. 1986. Emily Dickinson's Textbooks. Lafayette, CA: privately published.

Mitchell, Domhnall. 2000. "Northern Lights: Class, Color, Culture, and Emily Dickinson." Emily Dickinson Journal, 9(2):75-83.

OED. Oxford English Dictionary. 1961. 12 vols. Oxford: Clarendon Press, 1933.

Palmer, Leslie H. 1976. "ED's 'Father's Ground'-The Travel Motif of a Recluse Poet." Dickinson Studies 30:95-104.

Patterson, Rebecca. 1969. "Emily Dickinson's Geography: Latin America." Papers in Language and Literature 5:44157.

. 1979. "Emily Dickinson's Geography." Emily Dickinson's Imagery. Amherst: University of Massachusetts Press, 140-179.

Room, Adrian. Brezver's Dictionary of names. London: Cassett, 1992.

- Place-names of the world. North Carolina, London: McFarland and Company, 1997.

Silva Gruesz, Kirsten. 2004. "The Geographical Imagination in Whitman and Dickinson." The Classroom Electric: Dickinson, Whitman, and American Culture. http://www.iath.virginia.edu fdw/volume1/gruesz/ index.htm.

Urdang, Laurence, ed. Names and Nicknames of Places and Things. Boston: G.K. Hall and Co., 1987.

Webster, Noah. 1828. An American Dictionary of the English Language. San Francisco: Foundation for American Christian Education, 1967 Reprint.

. 1844. An American Dictionary of the English Language. 2 vols. New Haven: Webster. 